Article

\title{
Binary Nitrogen Precursor-Derived Porous Fe-N-S/C Catalyst for Efficient Oxygen Reduction Reaction in a Zn-Air Battery
}

\author{
Xiao Liu ${ }^{1,2}$, Chi Chen ${ }^{1}$, Qingqing Cheng ${ }^{1,2}$, Liangliang Zou ${ }^{1}$, Zhiqing Zou ${ }^{1, *}$ and Hui Yang ${ }^{1, *}$ \\ 1 Shanghai Advanced Research Institute, Chinese Academy of Sciences, Shanghai 201210, China; \\ liuxiao@sari.ac.cn (X.L.); chenchi@sari.ac.cn (C.C.); chengqinghc@163.com (Q.C.); zoull@sari.ac.cn (L.Z.) \\ 2 University of the Chinese Academy of Sciences, Beijing 100039, China \\ * Correspondence: zouzq@sari.ac.cn (Z.Z.); yangh@sari.ac.cn (H.Y.); Tel.: +86-21-2032-4112 (H.Y.)
}

Received: 2 March 2018; Accepted: 19 March 2018; Published: 13 April 2018

\begin{abstract}
It is still a challenge to synthesize non-precious-metal catalysts with high activity and stability for the oxygen reduction reaction (ORR) to replace the state-of-the art $\mathrm{Pt} / \mathrm{C}$ catalyst. Herein, a Fe, N, S co-doped porous carbon (Fe-NS/PC) is developed by using $\mathrm{g}-\mathrm{C}_{3} \mathrm{~N}_{4}$ and 2,4,6-tri(2-pyridyl)1,3,5-triazine (TPTZ) as binary nitrogen precursors. The interaction of binary nitrogen precursors not only leads to the formation of more micropores, but also increases the doping amount of both iron and nitrogen dispersed in the carbon matrix. After a second heat-treatment, the best $\mathrm{Fe} / \mathrm{NS} / \mathrm{C}-\mathrm{g}-\mathrm{C}_{3} \mathrm{~N}_{4} / \mathrm{TPTZ}-1000$ catalyst exhibits excellent ORR performance with an onset potential of $1.0 \mathrm{~V}$ vs. reversible hydrogen electrode (RHE) and a half-wave potential of $0.868 \mathrm{~V}$ (RHE) in alkaline medium. The long-term durability is even superior to the commercial $\mathrm{Pt} / \mathrm{C}$ catalyst. In the meantime, an assembled Zn-air battery with Fe/NS/C-g- $\mathrm{C}_{3} \mathrm{~N}_{4} / \mathrm{TPTZ}-1000$ as the cathode shows a maximal power density of $225 \mathrm{~mW} \cdot \mathrm{cm}^{-2}$ and excellent durability, demonstrating the great potential of practical applications in energy conversion devices.
\end{abstract}

Keywords: non-precious metal catalyst; oxygen reduction reaction; binary nitrogen precursors; g- ${ }_{3} \mathrm{~N}_{4} ; 2,4,6$-tri(2-pyridyl)-1,3,5-triazine

\section{Introduction}

The oxygen reduction reaction (ORR) plays an important role in the energy efficiency of polymer electrolyte membrane fuel cells (PEMFCs) and metal-air batteries (MABs). So far, platinum (Pt)-based materials are still the most effective catalysts for the ORR due to its sluggish kinetics. However, the high price and scarcity of Pt severely hinder the large-scale applications of PEMFCs and MABs. Therefore, extensive efforts have been devoted to develop low-cost and earth-abundant non-precious metal catalysts with efficient ORR performance. The transition metal $(\mathrm{M}=\mathrm{Fe}, \mathrm{Co}$, etc.) and nitrogen co-doped carbon materials (M-N-C), such as graphene [1,2], nanotube [3,4], and porous carbon $[5,6]$, have shown great progress in ORR electrocatalysis, especially for Fe-N-C materials, which have been considered as the most promising catalysts for substituting the expensive Pt catalysts [7-9].

The excellent ORR activity usually depends on two main factors, namely, the high intrinsic activity of single sites and high density of active sites. Therefore, the M-N-C electrocatalysts for efficient ORR require high heteroatom doping contents, high surface area, porous structure, and good conductivity [10-12]. Heteroatom doping is an effective method to tailor the electronic structure of electroneutral carbon matrix, which would facilitate the adsorption of $\mathrm{O}_{2}$. High surface area and porous structure are beneficial to increase the number of accessible active sites and facilitate the mass transport of the ORR relevant species approaching the internal active sites of catalysts $[13,14]$. Heat-treatment 
at high temperature is a vital process to form the ORR active centers, therefore, the precursors should be chosen carefully. Recently, the use of binary nitrogen precursors has been developed as an effective synthetic strategy to improve the porosity and heteroatoms doping contents, hence to improve the ORR activity. Wu et al. [15] synthesized a Fe-N-C catalyst derived from polyaniline (PANI) and dicyandiamide (DCDA) as binary nitrogen precursors, which possessed higher ORR activity than the individual PANI or DCDA-derived ones. The superior ORR activity can be ascribed to the increased content of pyridinic nitrogen doped into the carbon matrix. The combination of PANI and DCDA could enhance the porosity and increase the surface area, thanks to the different decomposition temperatures. Chen et al. [16] synthesized a class of Fe-N-C catalysts with 3D nanoporous structure using phenanthroline (Phen) and PANI as dual nitrogen sources. The Phen played the role of pore-creating agent due to its lower thermostability. A similar strategy was also reported by Zelenay et al. [17]. Moreover, it has been proved that the additional doping of $S$ atoms in the Fe-N-C catalyst will remarkably enhance the ORR activity [18]. However, although the development of non-precious metal catalysts has achieved great progress, the application of these materials in practical devices, such as PEMFCs and MABs, is still far from satisfactory, especially for the long-term stability [19].

In this work, we have developed a facile method to synthesize Fe, N, S co-doped porous carbon materials (Fe-NS/PC) as efficient ORR catalysts with g- $\mathrm{C}_{3} \mathrm{~N}_{4}$ and 2,4,6-tri(2-pyridyl)-1,3,5-triazine (TPTZ) as binary nitrogen precursors. The TPTZ is able to coordinate with $\mathrm{Fe}^{3+}$ [20], which could contribute to the uniformly-dispersed metal-containing species located at the $\mathrm{N}$-doped carbon skeleton $[21,22]$. The addition of g- $\mathrm{C}_{3} \mathrm{~N}_{4}$ sheets could inhibit the sintering of TPTZ during carbonization. The interaction of $\mathrm{g}^{-} \mathrm{C}_{3} \mathrm{~N}_{4}$ and TPTZ is beneficial to increase the doping amount of iron and nitrogen, and to facilitate the mass transfer of ORR relevant species. As a result, the binary nitrogen precursor-derived Fe-NS/PC catalyst exhibited better ORR performance than the single nitrogen precursor-derived ones. After second heat treatment, the $\mathrm{Fe} / \mathrm{NS} / \mathrm{C}-\mathrm{g}-\mathrm{C}_{3} \mathrm{~N}_{4} / \mathrm{TPTZ}$ catalyst shows enhanced activity and long-term durability. The best ORR activity of $\mathrm{Fe} / \mathrm{NS} / \mathrm{C}-\mathrm{g}-\mathrm{C}_{3} \mathrm{~N}_{4} / \mathrm{TPTZ}-1000$ is even superior to that of the state-of-the art $\mathrm{Pt} / \mathrm{C}$ catalyst. A Zn-air battery with the $\mathrm{Fe} / \mathrm{NS} / \mathrm{C}-\mathrm{g}-\mathrm{C}_{3} \mathrm{~N}_{4} / \mathrm{TPTZ}-1000$ cathode exhibits a maximal power density of $225 \mathrm{~mW} \cdot \mathrm{cm}^{-2}$ at room temperature and superior stability with only $4.03 \%$ loss of output voltage at a current density of $20 \mathrm{~mA} \cdot \mathrm{cm}^{-2}$ after $20,000 \mathrm{~s}$.

\section{Results and Discussion}

Figure 1a-c show the scanning electron microscope (SEM) images of the as-synthesized Fe-NS/PC catalysts using $\mathrm{g}-\mathrm{C}_{3} \mathrm{~N}_{4}$ and TPTZ separated as single nitrogen precursor and together as binary nitrogen precursors, denoted as Fe/NS/C-g- $\mathrm{C}_{3} \mathrm{~N}_{4}$, Fe/NS/C-TPTZ, and Fe/NS/C-g- $\mathrm{C}_{3} \mathrm{~N}_{4} / \mathrm{TPTZ}$, respectively. The Fe/NS/C-g- $\mathrm{C}_{3} \mathrm{~N}_{4}$ has a fluffy morphology with high porosity (Figure 1a). By contrast, $\mathrm{Fe} / \mathrm{NS} / \mathrm{C}-\mathrm{TPTZ}$ shows a denser morphology (Figure 1b), probably because of the collapse of the carbon skeleton during heat-treatment. Through the combination of both $\mathrm{g}-\mathrm{C}_{3} \mathrm{~N}_{4}$ and TPTZ with various thermal stability (Figure S1), the Fe/NS/C-g- $\mathrm{C}_{3} \mathrm{~N}_{4} / \mathrm{TPTZ}$ preserves the fluffy morphology (Figure 1c), probably due to the fact that the mixed g- $\mathrm{C}_{3} \mathrm{~N}_{4}$ sheets prevent the sintering of TPTZ.

The effects of $\mathrm{N}$ precursors on BET surface areas and pore structures were studied by $\mathrm{N}_{2}$ adsorption-desorption isotherms. As can be seen in Figure 1d,f, the Fe/NS/C-g- $\mathrm{C}_{3} \mathrm{~N}_{4}$ exhibits a highest BET surface area of $928 \mathrm{~m}^{2} / \mathrm{g}$, the most of which are external surface area. The micropore area is only $82 \mathrm{~m}^{2} / \mathrm{g}$. The Fe/NS/C-TPTZ shows a slightly lower BET surface area of $849 \mathrm{~m}^{2} / \mathrm{g}$, but a much larger micropore area of $317 \mathrm{~m}^{2} / \mathrm{g}$. However, the amounts of mesopores and macropores are relatively few (Figure 1e), which are consistent with the dense structure displayed by SEM image (Figure 1b). After the combination of $\mathrm{g}-\mathrm{C}_{3} \mathrm{~N}_{4}$ and TPTZ, although the BET surface area slightly decreases $\left(759 \mathrm{~m}^{2} / \mathrm{g}\right)$, the $\mathrm{Fe} / \mathrm{NS} / \mathrm{C}-\mathrm{g}-\mathrm{C}_{3} \mathrm{~N}_{4} / \mathrm{TPTZ}$ catalyst integrates the micropores of Fe/NS/C-TPTZ and the fluffy structure of $\mathrm{Fe} / \mathrm{NS} / \mathrm{C}-\mathrm{g}-\mathrm{C}_{3} \mathrm{~N}_{4}$ (Figure 1f), which might facilitate the mass transfer and the ORR catalytic activity $[23,24]$. 
X-ray diffraction (XRD) was carried out to characterize the crystal structure of the Fe-NS/PC catalysts. According to the XRD patterns in Figure 1g, the Fe/NS/C-TPTZ exhibits two main diffraction peaks at around $25.5^{\circ}$ and $43^{\circ}$, associated to the (002) and (100) planes of graphitic carbon, respectively. The (002) diffraction peak of the Fe/NS/C-g- $\mathrm{C}_{3} \mathrm{~N}_{4}$ shifts to a higher angle of $29.8^{\circ}$, which can be associated with the carbon nitride (PDF-\#78-1747). Noteworthy, the binary nitrogen precursor-derived $\mathrm{Fe} / \mathrm{NS} / \mathrm{C}-\mathrm{g}-\mathrm{C}_{3} \mathrm{~N}_{4} / \mathrm{TPTZ}$ displays a broad peak at around $25.8^{\circ}$ corresponding to the (002) diffraction of graphitic carbon, and a weak swell at $29.8^{\circ}$ corresponding to the carbon nitride, which clearly indicates the interaction between two nitrogen precursors during pyrolysis. No other diffraction peaks can be observed, demonstrating the absence of any other Fe-containing crystalline phases.

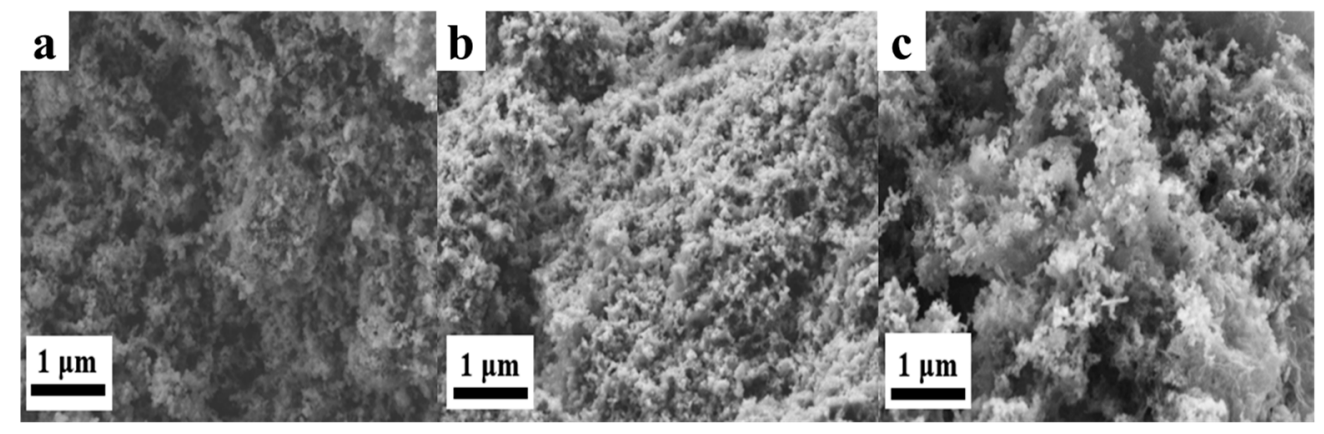

(d)

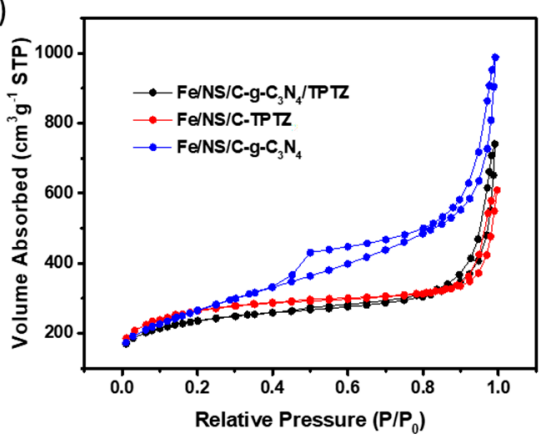

(f)

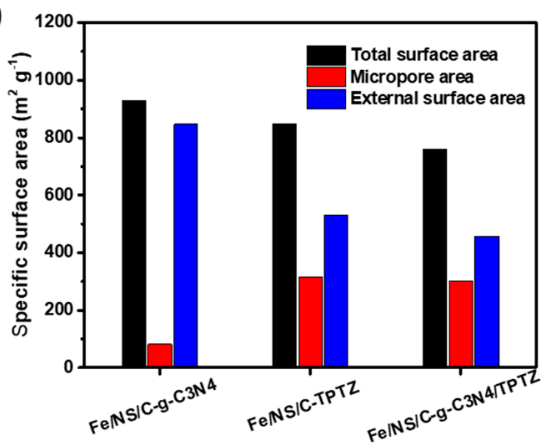

(e)

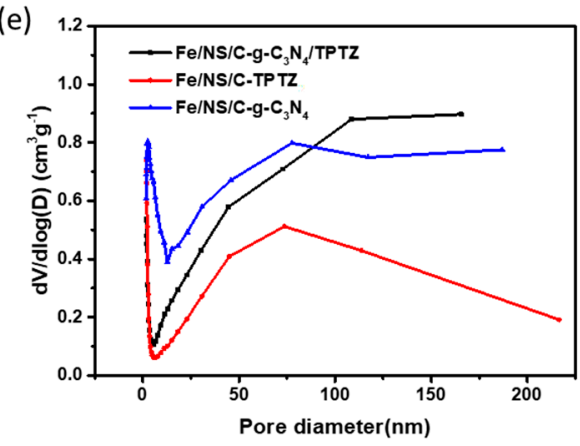

(g)

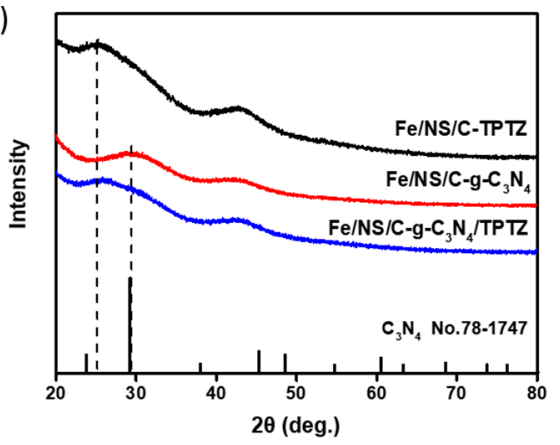

Figure 1. Scanning electron microscope (SEM) images of (a) Fe/NS/C-g- $\mathrm{C}_{3} \mathrm{~N}_{4}$, (b) $\mathrm{Fe} / \mathrm{NS} / \mathrm{C}-$ TPTZ (TPTZ: 2,4,6-tri(2-pyridyl)-1,3,5-triazine), and (c) Fe/NS/C-g- $\mathrm{C}_{3} \mathrm{~N}_{4} /$ TPTZ; (d) $\mathrm{N}_{2}$ adsorptiondesorption isotherms; (e) corresponding pore size distributions; (f) comparison of BET surface areas; and (g) X-ray diffraction (XRD) patterns of Fe/NS/C-g- $\mathrm{C}_{3} \mathrm{~N}_{4}, \mathrm{Fe} / \mathrm{NS} / \mathrm{C}-\mathrm{TPTZ}$, and Fe/NS/ C-g- $\mathrm{C}_{3} \mathrm{~N}_{4} / \mathrm{TPTZ}$.

X-ray photoelectron spectroscopy (XPS) was implemented to investigate the states of each component within the Fe-NS/PC catalysts. The survey XPS spectra (Figure 2a) reveal that the main elements of Fe-NS/PC catalysts consist of Fe, N, C, O, and S. The elemental compositions are summarized in Table S1. Figure $2 b-d$ display the high resolution N 1s spectra of the three Fe-NS/PC catalysts. All the spectra can be deconvoluted into four peaks corresponding to pyridinic N (N1, 
398.1-398.7 eV), pyrrolic N (N2, 399.78-400.7 eV), graphitic N (N3, 400.99-401.3 eV), and oxidized $\mathrm{N}(\mathrm{N} 4,402-404.27 \mathrm{eV})[25,26]$, respectively. Previous reports have demonstrated that both pyridinic $\mathrm{N}$ and graphitic $\mathrm{N}$ may participate the oxygen reduction reaction [27-29]. These two $\mathrm{N}$ species $(\mathrm{N} 1+\mathrm{N} 3)$ account for 4.03 at $\%$ of all the elements in Fe/NS/C-g- $\mathrm{C}_{3} \mathrm{~N}_{4} / \mathrm{TPTZ}$, remarkably higher than that of $\mathrm{Fe} / \mathrm{NS} / \mathrm{C}-\mathrm{g}-\mathrm{C}_{3} \mathrm{~N}_{4}(1.88 \%)$ and Fe/NS/C-TPTZ (3.46\%), as shown in Table S1. Notably, the contents of $\mathrm{Fe}$ and $\mathrm{N}$ in $\mathrm{Fe} / \mathrm{NS} / \mathrm{C}-\mathrm{g}-\mathrm{C}_{3} \mathrm{~N}_{4} / \mathrm{TPTZ}$ are 0.29 at $\%$ and $6.67 \mathrm{at} \%$, respectively, both of which are the highest among the three catalysts. In addition, the co-doping of $\mathrm{S}$ element in Fe-N-C catalysts would further improve the ORR activity, probably due to the structural defects and electron distribution induced by S atoms [30,31]. Based on the consideration of the high heteroatoms doping contents combined with the porous structure, the high ORR activity could be expected for the $\mathrm{Fe} / \mathrm{NS} / \mathrm{C}-\mathrm{g}-\mathrm{C}_{3} \mathrm{~N}_{4} / \mathrm{TPTZ}$ catalyst.
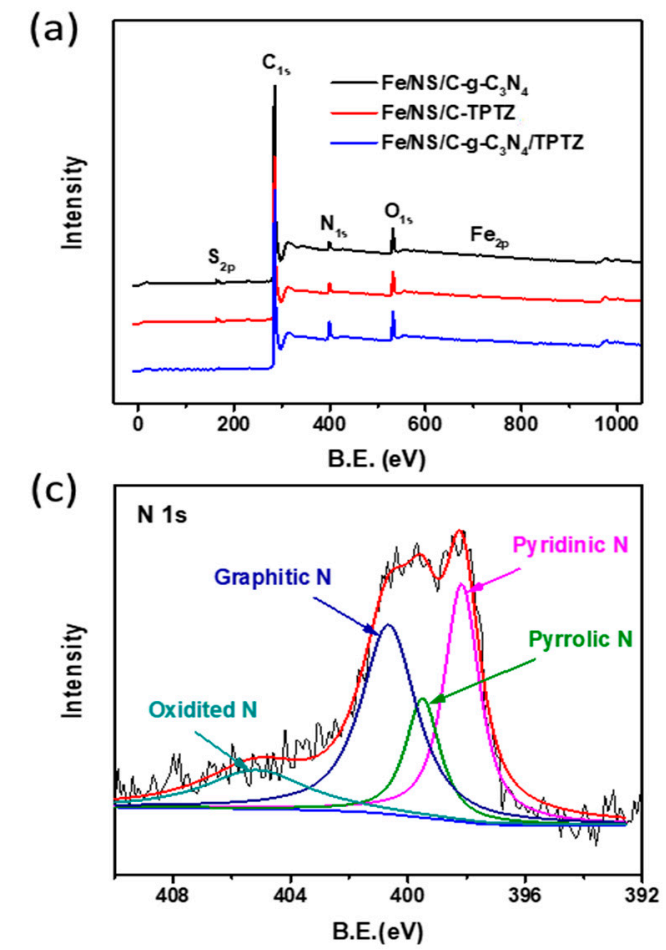

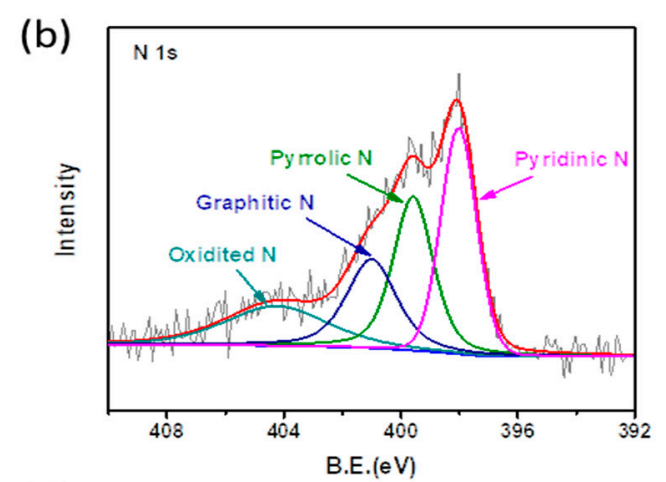

(d)

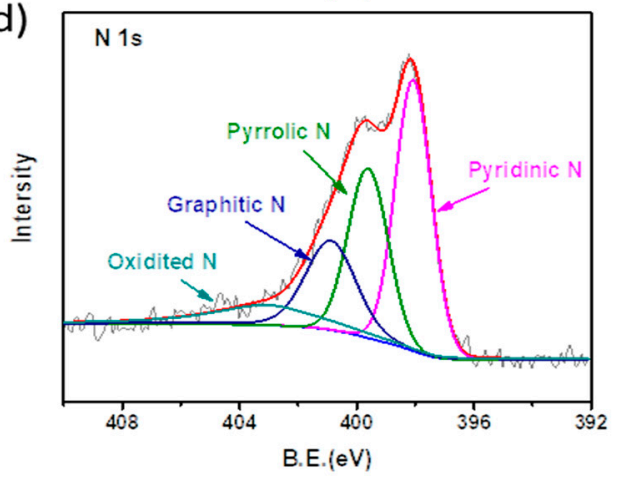

Figure 2. (a) X-ray photoelectron spectroscopy (XPS) survey spectra of $\mathrm{Fe} / \mathrm{NS} / \mathrm{C}-\mathrm{g}-\mathrm{C}_{3} \mathrm{~N}_{4}$, $\mathrm{Fe} / \mathrm{NS} / \mathrm{C}-\mathrm{TPTZ}$, and $\mathrm{Fe} / \mathrm{NS} / \mathrm{C}-\mathrm{g}-\mathrm{C}_{3} \mathrm{~N}_{4} / \mathrm{TPTZ}$ catalysts; high-resolution $\mathrm{N}$ 1s XPS spectra of (b) $\mathrm{Fe} / \mathrm{NS} / \mathrm{C}-\mathrm{g}-\mathrm{C}_{3} \mathrm{~N}_{4}$, (c) Fe/NS/C-TPTZ, and (d) Fe/NS/C-g- $\mathrm{C}_{3} \mathrm{~N}_{4} / \mathrm{TPTZ}$.

The ORR activity of the Fe-NS/PC catalysts were evaluated by rotating disk electrode (RDE) test in $\mathrm{O}_{2}$-saturated $0.1 \mathrm{M} \mathrm{KOH}$ solution. As displayed in Figure 3, the Fe/NS/C-g- $\mathrm{C}_{3} \mathrm{~N}_{4} / \mathrm{TPTZ}$ catalyst exhibits the best ORR activity with an onset $\left(E_{0}\right)$ and half-wave $\left(E_{1 / 2}\right)$ potential of $0.95 \mathrm{~V}$ and $0.853 \mathrm{~V}$ (RHE), respectively, higher than that of $\mathrm{Fe} / \mathrm{NS} / \mathrm{C}-\mathrm{g}-\mathrm{C}_{3} \mathrm{~N}_{4}$ catalyst $\left(E_{0}=0.946 \mathrm{~V}\right.$ and $\left.E_{1 / 2}=0.843 \mathrm{~V}\right)$. By sharp contrast, the Fe/NS/C-TPTZ shows inferior ORR activity with $E_{0}=0.917 \mathrm{~V}$ (RHE) and much smaller diffusion-limited current, probably due to the agglomerations of sintered carbon that are difficult to disperse obstruct the transfer of ORR-related species, in spite of the high BET surface area. The presence of $\mathrm{g}-\mathrm{C}_{3} \mathrm{~N}_{4}$ in dual nitrogen precursors might avoid the sintering of TPTZ, meanwhile maintain the fluffy structure and increase the $\mathrm{Fe}, \mathrm{N}$ doping content, thus resulting in the full exposure of active sites, which could be responsible for the high ORR activity of the $\mathrm{Fe} / \mathrm{NS} / \mathrm{C}-\mathrm{g}-\mathrm{C}_{3} \mathrm{~N}_{4} / \mathrm{TPTZ}$ catalyst. 


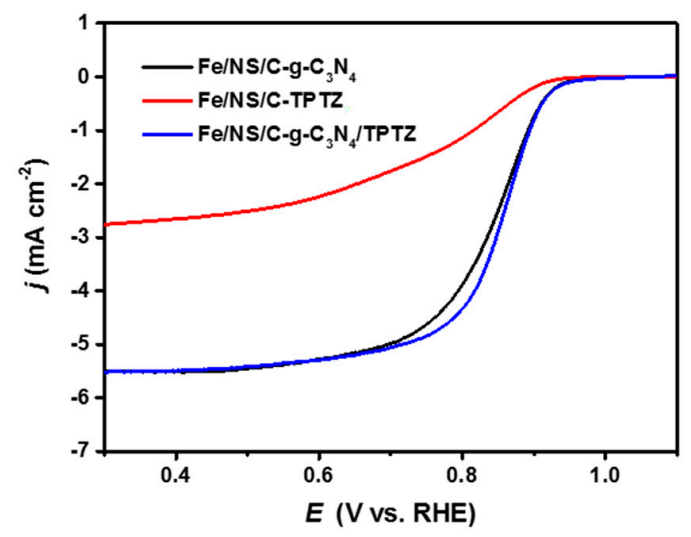

Figure 3. Oxygen reduction reaction (ORR) polarization curves of Fe/NS/C-g- $\mathrm{C}_{3} \mathrm{~N}_{4}, \mathrm{Fe} / \mathrm{NS} / \mathrm{C}-\mathrm{TPTZ}$, and $\mathrm{Fe} / \mathrm{NS} / \mathrm{C}-\mathrm{g}-\mathrm{C}_{3} \mathrm{~N}_{4} / \mathrm{TPTZ}$ catalysts in $\mathrm{O}_{2}$-saturated $0.1 \mathrm{M} \mathrm{KOH}$ with a rotating speed of $1600 \mathrm{rpm}$ and at a scan rate of $10 \mathrm{mV} \mathrm{s}^{-1}$. RHE: reversible hydrogen electrode.

To further improve the ORR performance, a secondary heat treatment was conducted to the best $\mathrm{Fe} / \mathrm{NS} / \mathrm{C}-\mathrm{g}-\mathrm{C}_{3} \mathrm{~N}_{4} / \mathrm{TPTZ}$ catalyst at the range of $800-1000{ }^{\circ} \mathrm{C}$, denoted as $\mathrm{Fe} / \mathrm{NS} / \mathrm{C}-\mathrm{g}-\mathrm{C}_{3} \mathrm{~N}_{4} / \mathrm{TPTZ}-\mathrm{T}$ $(\mathrm{T}=800,900,1000)$. Figure $4 \mathrm{a}-\mathrm{h}$ present the transmission electron microscope (TEM) images of $\mathrm{Fe} / \mathrm{NS} / \mathrm{C}-\mathrm{g}-\mathrm{C}_{3} \mathrm{~N}_{4} / \mathrm{TPTZ}$, and Fe/NS/C-g- $\mathrm{C}_{3} \mathrm{~N}_{4} / \mathrm{TPTZ}-\mathrm{T}(\mathrm{T}=800,900,1000)$ at diversed magnifications. All these samples show the morphological characteristics of agglomerations of amorphous carbon nanoparticles with the diameter of 20-50 nm. No crystalline iron-containing nanoparticles can be observed for all three catalysts, indicating no agglomerations of iron formed during the second heat treatment. The energy dispersive X-ray spectroscopy (EDX) mapping analysis of $\mathrm{Fe} / \mathrm{NS} / \mathrm{C}-\mathrm{g}-\mathrm{C}_{3} \mathrm{~N}_{4} / \mathrm{TPTZ}-1000$ was also carried out to observe the elemental distributions. As can be seen in Figure 4i, the TEM image and the corresponding elemental mapping reveal that all doping heteroatoms, which are regarded as the components of the ORR active sites, are uniformly distributed throughout the carbon matrix, leading to the full exposure of the active sites to the ORR related species.

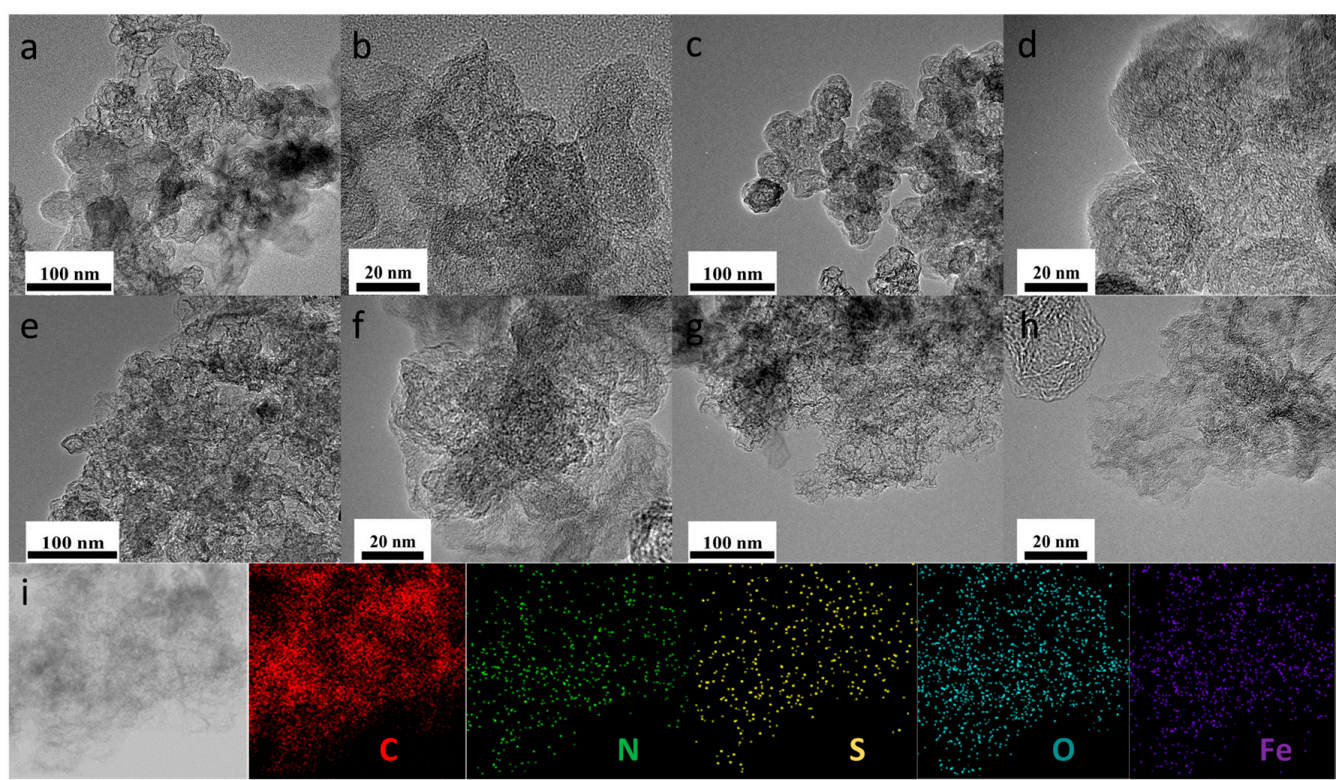

Figure 4. Transmission electron microscope (TEM) images of (a,b) Fe/NS/C-g- $\mathrm{C}_{3} \mathrm{~N}_{4} / \mathrm{TPTZ}$; (c,d) $\mathrm{Fe} / \mathrm{NS} / \mathrm{C}-\mathrm{g}-\mathrm{C}_{3} \mathrm{~N}_{4}$ /TPTZ-800; (e,f) Fe/NS/C-g-C $\mathrm{N}_{4}$ /TPTZ-900; (g,h) Fe/NS/C-g-C $\mathrm{N}_{4}$ /TPTZ-1000; and (i) TEM-EDX (EDX: energy dispersive $X$-ray spectroscopy) mapping analysis of $\mathrm{C}, \mathrm{N}, \mathrm{S}, \mathrm{O}$, and Fe of Fe/NS/C-g- $\mathrm{C}_{3} \mathrm{~N}_{4} / \mathrm{TPTZ}-1000$. 
After a second heat treatment at different temperatures, all three Fe/NS/C-g- $\mathrm{C}_{3} \mathrm{~N}_{4} / \mathrm{TPTZ}-\mathrm{T}(\mathrm{T}=800$, 900,1000 ) catalysts show two main diffraction peaks at around $29.8^{\circ}$ and $43^{\circ}$ (Figure 5a), similar to $\mathrm{Fe} / \mathrm{NS} / \mathrm{C}-\mathrm{g}-\mathrm{C}_{3} \mathrm{~N}_{4}$. There are no other diffraction peaks appear, further demonstrating the absence of crystalline iron-containing phases, which is consistent with the TEM results (Figure 4). Figure 5b displays the $\mathrm{N}_{2}$ adsorption-desorption isotherms of the Fe/NS/C-g-C $\mathrm{N}_{4} / \mathrm{TPTZ}-\mathrm{T}(\mathrm{T}=800$, 900, 1000) catalysts. The BET suface areas of Fe/NS/C-g- $\mathrm{C}_{3} \mathrm{~N}_{4} / \mathrm{TPTZ}-800, \mathrm{Fe} / \mathrm{NS} / \mathrm{C}-\mathrm{g}-\mathrm{C}_{3} \mathrm{~N}_{4} / \mathrm{TPTZ}-900$, and Fe/NS/C-g-C $\mathrm{C}_{3}$ /TPTZ-1000 are $876.8 \mathrm{~m}^{2} \mathrm{~g}^{-1}, 1026.4 \mathrm{~m}^{2} \mathrm{~g}^{-1}, 1138.9 \mathrm{~m}^{2} \mathrm{~g}^{-1}$, respectively. The pore size distributions of the Fe/NS/C-g- $\mathrm{C}_{3} \mathrm{~N}_{4} / \mathrm{TPTZ}-\mathrm{T}(\mathrm{T}=800,900,1000)$ indicate that the three catalysts all possess a good porous structure (Figure $5 \mathrm{c}$ ).
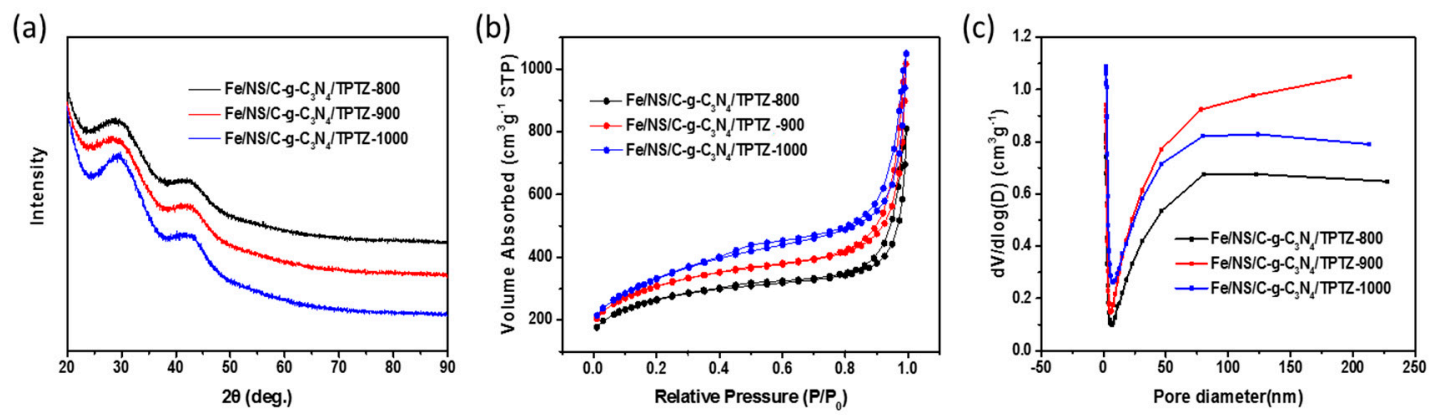

Figure 5. (a) XRD patterns; (b) $\mathrm{N}_{2}$ adsorption-desorption isotherms; and (c) corresponding pore size distributions of Fe/NS/C-g- $\mathrm{C}_{3} \mathrm{~N}_{4}$ /TPTZ-800, Fe/NS/C-g- $\mathrm{C}_{3} \mathrm{~N}_{4}$ /TPTZ-900, and Fe/NS/ C-g- $\mathrm{C}_{3} \mathrm{~N}_{4} / \mathrm{TPTZ}-1000$.

The XPS survey spectra of Fe/NS/C-g-C $\mathrm{N}_{4} / \mathrm{TPTZ}$ and Fe/NS/C-g-C $\mathrm{N}_{4} / \mathrm{TPTZ}-\mathrm{T}$ (T = 800, 900, 1000) were collected to measure the elemental compositions, as shown in Figure 6a and Table S2. The contents of doped $\mathrm{Fe}$ and $\mathrm{N}$ elements reduce along with the secondary heat treatment temperature elevates. The $\mathrm{N}$ doping contents of Fe/NS/C-g- $\mathrm{C}_{3} \mathrm{~N}_{4} / \mathrm{TPTZ}-\mathrm{T}(\mathrm{T}=800,900,1000)$ are $4.48 \%, 2.57 \%$, and $1.40 \%$, respectively, all lower than that of Fe/NS/C-g- $\mathrm{C}_{3} \mathrm{~N}_{4} / \mathrm{TPTZ}$, due to the formation of gaseous $\mathrm{N}$-containing phases. The deconvoluted high-resolution $\mathrm{N} 1$ s spectra reveal that the pyridinic $\mathrm{N}$ and graphitic $\mathrm{N}$ predominate in all three catalysts, as shown in Figure $6 \mathrm{~b}-\mathrm{d}$ and summarized in Table S2. The high-resolution S 2p spectrum of Fe/NS/C-g- $\mathrm{C}_{3} \mathrm{~N}_{4} / \mathrm{TPTZ}-1000$ can be deconvoluted into three peaks, as shown in Figure 6e. The two peaks at 164.0 and $165.2 \mathrm{eV}$ can be described to $S 2 p_{3 / 2}$ and $S 2 p_{1 / 2}$ of thiophene-like C-S-C structure, respectively [32,33], while the third peak at $167.3 \mathrm{eV}$ corresponds to sulfate species. The synergetic effects of N, S co-doping would significantly improve the ORR activity by reducing the electron localization around the Fe centers, and improve the interaction with oxygen, facilitating the four-electron pathway [34]. The high-resolution Fe $2 p$ spectrum of Fe/NS/C-g-C $\mathrm{C}_{3} \mathrm{~N}_{4} / \mathrm{TPTZ}-1000$ presents two major peaks at around 711 and $724 \mathrm{eV}$, corresponding to Fe $2 \mathrm{p}_{1 / 2}$ and Fe $2 \mathrm{p}_{3 / 2}$, respectively (Figure 6f) [15,35]. The dominant peak at $711 \mathrm{eV}$ can be assigned to $\mathrm{Fe}^{3+}$ or $\mathrm{Fe}^{2+}$ coordinated with $\mathrm{N}$, which are suggested to be the ORR active centers $[15,36]$. The peak at $718.5 \mathrm{eV}$ is a satellite peak indicating the co-existence of $\mathrm{Fe}^{3+}$ and $\mathrm{Fe}^{2+}$ in the $\mathrm{Fe} / \mathrm{NS} / \mathrm{C}-\mathrm{g}-\mathrm{C}_{3} \mathrm{~N}_{4} / \mathrm{TPTZ}-1000$ [35]. 

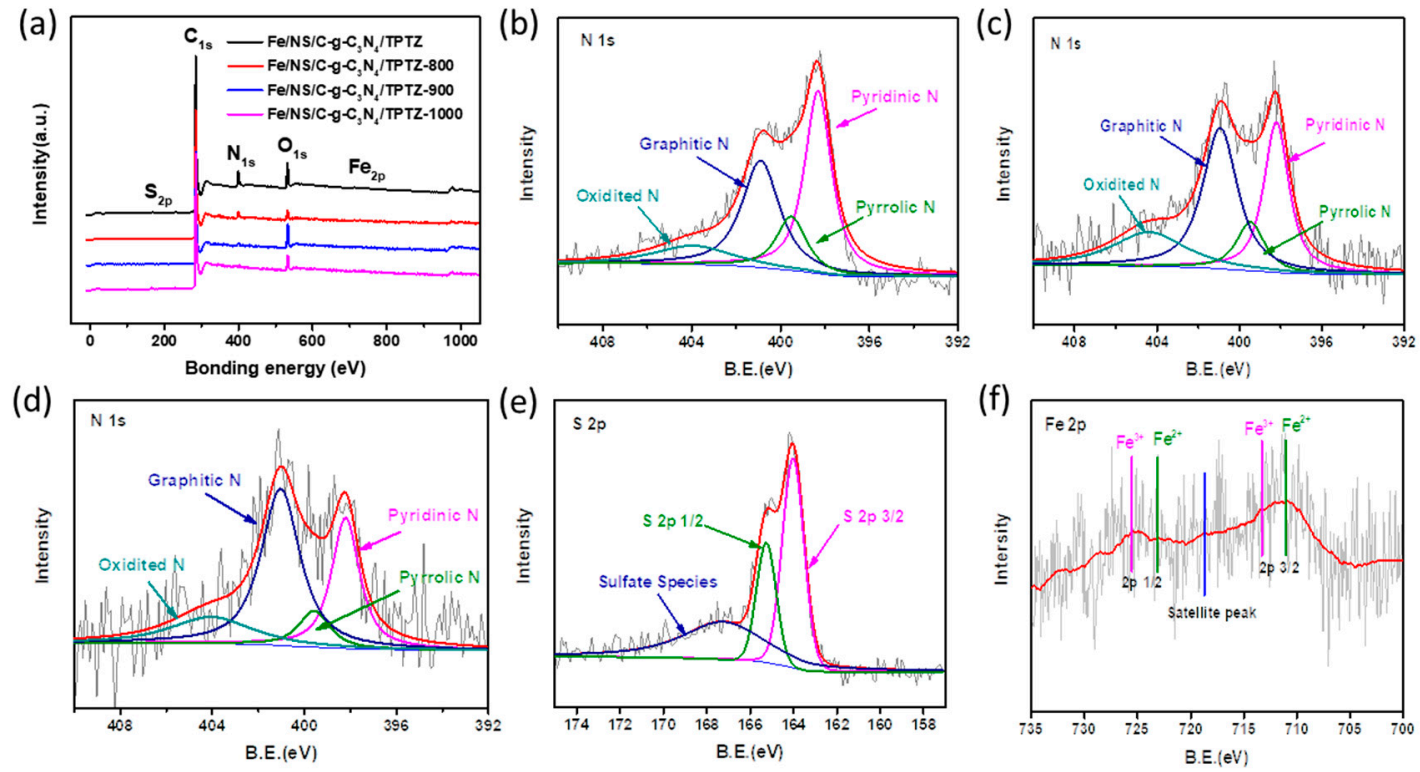

Figure 6. (a) XPS survey spectra of $\mathrm{Fe} / \mathrm{NS} / \mathrm{C}-\mathrm{g}-\mathrm{C}_{3} \mathrm{~N}_{4} / \mathrm{TPTZ}$ and $\mathrm{Fe} / \mathrm{NS} / \mathrm{C}-\mathrm{g}-\mathrm{C}_{3} \mathrm{~N}_{4} / \mathrm{TPTZ}-\mathrm{T}$ ( $\mathrm{T}=800,900,1000)$; high-resolution $\mathrm{N}$ 1s spectra of (b) Fe/NS/C-g- $\mathrm{C}_{3} \mathrm{~N}_{4} / \mathrm{TPTZ}-800$, (c) Fe/NS/Cg- $\mathrm{C}_{3} \mathrm{~N}_{4}$ /TPTZ-900 and (d) Fe/NS/C-g- $\mathrm{C}_{3} \mathrm{~N}_{4} /$ TPTZ-1000; (e) high-resolution $\mathrm{S} 2 \mathrm{p}$ spectrum and (f) Fe $2 \mathrm{p}$ spectrum of $\mathrm{Fe} / \mathrm{NS} / \mathrm{C}-\mathrm{g}-\mathrm{C}_{3} \mathrm{~N}_{4} / \mathrm{TPTZ}-1000$.

The ORR activities of Fe/NS/C-g- $\mathrm{C}_{3} \mathrm{~N}_{4} / \mathrm{TPTZ}-\mathrm{T}(\mathrm{T}=800,900,1000)$ catalysts were measured in $\mathrm{O}_{2}$-saturated $0.1 \mathrm{M} \mathrm{KOH}$ solution. For a comparison, commercial $\mathrm{Pt} / \mathrm{C}(20 \mathrm{wt} \%)$ catalyst was also evaluated. As displayed in Figure $7 \mathrm{a}$, after secondary heat treatment, the ORR activity of the $\mathrm{Fe} / \mathrm{NS} / \mathrm{C}-\mathrm{g}-\mathrm{C}_{3} \mathrm{~N}_{4} / \mathrm{TPTZ}$ is further improved. Fe/NS/C-g- $\mathrm{C}_{3} \mathrm{~N}_{4} / \mathrm{TPTZ}-800$ and $\mathrm{Fe} / \mathrm{NS} / \mathrm{C}-\mathrm{g}-\mathrm{C}_{3} \mathrm{~N}_{4} / \mathrm{TPTZ}-900$ exhibit similar activity with the half-wave potential $\left(E_{1 / 2}\right)$ of $0.863 \mathrm{~V}$ and $0.864 \mathrm{~V}$ (RHE), respectively. The best ORR activity is achieved at Fe/NS/C-g- $\mathrm{C}_{3} \mathrm{~N}_{4} / \mathrm{TPTZ}-1000$ with the onset and half-wave potential of $1.0 \mathrm{~V}$ and $0.868 \mathrm{~V}$ (RHE), respectively, higher than that of $\mathrm{Pt} / \mathrm{C}$ catalyst $\left(E_{0}=0.97 \mathrm{~V}, E_{1 / 2}=0.841 \mathrm{~V}\right)$. To evaluate the intrinsic catalytic activity, the mass activity $\left(j_{m}\right)$ was calculated based on the Koutecky-Levich equation (Table S3). The Fe/NS/C-g- $\mathrm{C}_{3} \mathrm{~N}_{4} / \mathrm{TPTZ}-1000$ catalyst shows the best mass activity of $5.73 \mathrm{~A} \mathrm{~g}^{-1}$ at $0.9 \mathrm{~V}$, reaching up to $48.8 \%$ of that of $\mathrm{Pt} / \mathrm{C}$ (11.73 $\left.\mathrm{A} \mathrm{g}^{-1}\right)$.

To explore the origin of the high ORR activity, we have probed the possible role of $\mathrm{Fe}$ and $\mathrm{S}$ within the Fe-NS/PC catalysts. As shown in Figure S2, Fe/N/C-g- $\mathrm{C}_{3} \mathrm{~N}_{4} / \mathrm{TPTZ}-1000$ without sulfur doping exhibits lower onset and half-wave potentials for the ORR than $\mathrm{Fe} / \mathrm{NS} / \mathrm{C}-\mathrm{g}$ $\mathrm{C}_{3} \mathrm{~N}_{4}$ /TPTZ-1000, indicating the promoting effects of sulfur co-doping. By sharp comparison, the NS/C-g- $\mathrm{C}_{3} \mathrm{~N}_{4} / \mathrm{TPTZ}-1000$ without Fe doping presents inferior activity, with the half-wave potential $64 \mathrm{mV}$ lower than that of $\mathrm{Fe} / \mathrm{NS} / \mathrm{C}-\mathrm{g}-\mathrm{C}_{3} \mathrm{~N}_{4} / \mathrm{TPTZ}-1000$. These results definitely reflect the indispensable roles of $\mathrm{Fe}$ and $\mathrm{S}$ doping in Fe-NS/PC for high ORR activity. It is well known that $\mathrm{SCN}^{-}$can strongly coordinate with Fe atoms. As shown in Figure 33 , the Fe/NS/C-g- $\mathrm{C}_{3} \mathrm{~N}_{4} / \mathrm{TPTZ}-1000$ catalyst shows obvious ORR activity degradation after injecting $5 \mathrm{mM} \mathrm{SCN}^{-}$, the remaining ORR activity probably results from the N, $\mathrm{S}$ co-doped carbon materials. Interestingly, the ORR activity of the $\mathrm{Fe} / \mathrm{NS} / \mathrm{C}-\mathrm{g}-\mathrm{C}_{3} \mathrm{~N}_{4} / \mathrm{TPTZ}-1000$ can almost recover after rinsing and replacing with fresh electrolyte, indicating that $\mathrm{Fe}$ atoms are at least part of the ORR active sites.

Figure $7 \mathrm{~b}$ shows the hydrogen peroxide yield $\left(\mathrm{H}_{2} \mathrm{O}_{2} \%\right)$ and the electron transfer number $(\mathrm{n})$ of Fe/NS/C-g- $\mathrm{C}_{3} \mathrm{~N}_{4} / \mathrm{TPTZ}-1000$ calculated from disk current $\left(I_{\mathrm{d}}\right)$ and ring current $\left(I_{\mathrm{r}}\right)$ obtained by rotating ring-disk electrode (RRDE) test. The $\mathrm{H}_{2} \mathrm{O}_{2}$ yield is lower than $1.0 \%$ over the whole potential range. The corresponding electron transfer number is calculated to be larger than 3.975. Notably, the $\mathrm{H}_{2} \mathrm{O}_{2}$ starts to generate at the potential lower than $0.8 \mathrm{~V}$, where the ORR polarization curve has 
reached the diffusion-limited current. These results indicate a direct four-electron pathway of ORR on the Fe/NS/C-g- $\mathrm{C}_{3} \mathrm{~N}_{4} / \mathrm{TPTZ}-1000$. The Tafel plots of Fe/NS/C-g- $\mathrm{C}_{3} \mathrm{~N}_{4} / \mathrm{TPTZ}-1000$ depicted in Figure $7 \mathrm{c}$ show the Tafel slope of $68 \mathrm{mV} \mathrm{dec}^{-1}$, closed to that of $\mathrm{Pt} / \mathrm{C}$ catalyst $\left(73 \mathrm{mV} \mathrm{dec}^{-1}\right)$.
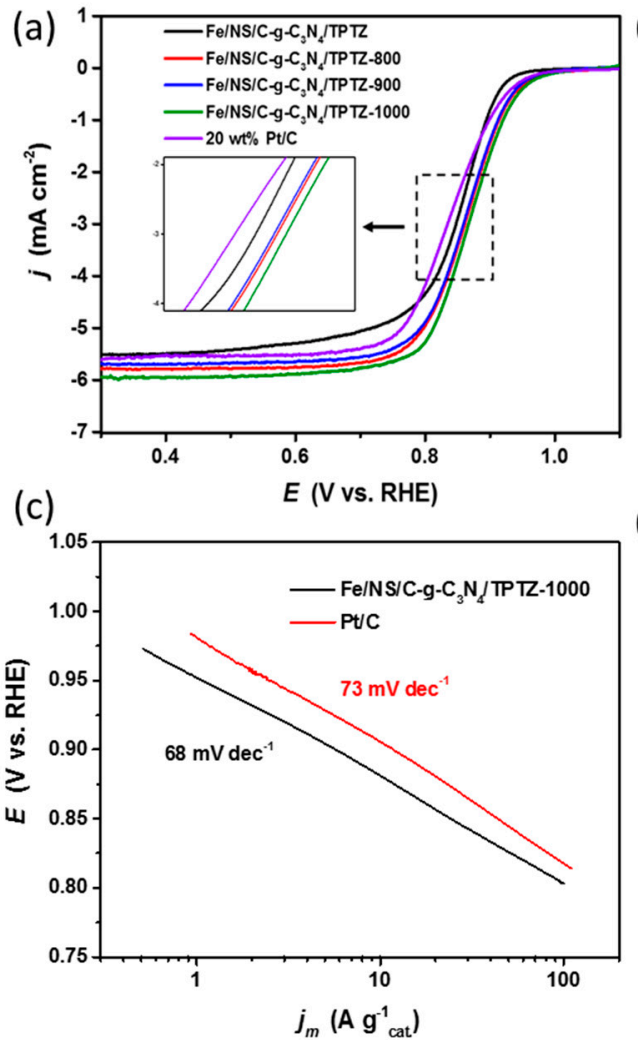

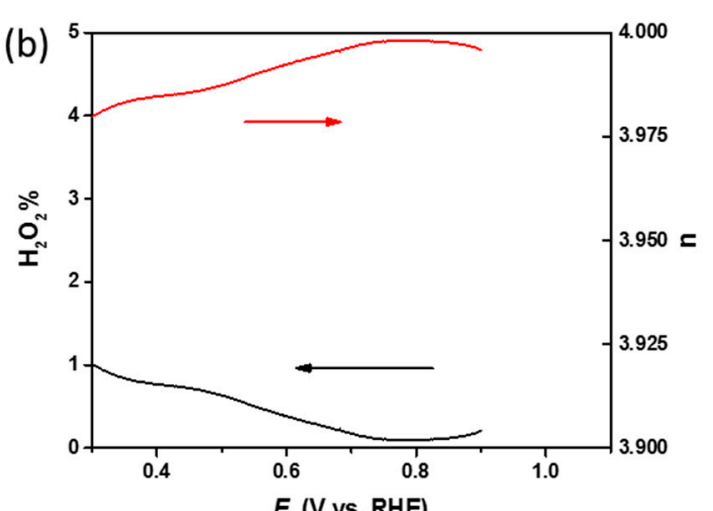

(d)

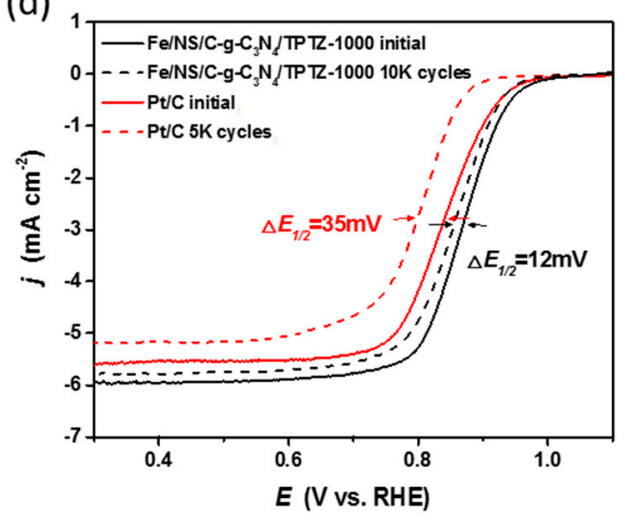

Figure 7. (a) ORR polarization curves of Fe/NS/C-g- $\mathrm{C}_{3} \mathrm{~N}_{4} / \mathrm{TPTZ}, \mathrm{Fe} / \mathrm{NS} / \mathrm{C}-\mathrm{g}-\mathrm{C}_{3} \mathrm{~N}_{4} / \mathrm{TPTZ}-\mathrm{T}(\mathrm{T}=800$, $900,1000)$ and $\mathrm{Pt} / \mathrm{C}$ catalyst in $\mathrm{O}_{2}$-saturated $0.1 \mathrm{M} \mathrm{KOH}$ solution with a rotational speed of $1600 \mathrm{rpm}$ and at a scan rate of $10 \mathrm{mV} / \mathrm{s}$; (b) hydrogen peroxide yield and electron transfer number of $\mathrm{Fe} / \mathrm{NS} / \mathrm{C}-\mathrm{g}-\mathrm{C}_{3} \mathrm{~N}_{4} / \mathrm{TPTZ}-1000$ catalyst, (c) Tafel plots of Fe/NS/C-g-C $\mathrm{N}_{4} / \mathrm{TPTZ}-1000$ and Pt/C; and (d) ORR polarization curves of Fe/NS/C-g- $\mathrm{C}_{3} \mathrm{~N}_{4} / \mathrm{TPTZ}-1000$ (before and after 10,000 potential cycles) and $\mathrm{Pt} / \mathrm{C}$ (before and after 5000 potential cycles).

An accelerated durability test (ADT) was carried out to assess the durability of Fe/NS/ C-g- $\mathrm{C}_{3} \mathrm{~N}_{4} / \mathrm{TPTZ}-1000$ catalyst by potential-cycling between 0.6 and $1.1 \mathrm{~V}$ at a scan rate of $50 \mathrm{mV} \mathrm{s}^{-1}$ in $\mathrm{O}_{2}$-saturated $0.1 \mathrm{M} \mathrm{KOH}$. As shown in Figure $7 \mathrm{~d}$, after 10,000 cycles, the $E_{1 / 2}$ of $\mathrm{Fe} / \mathrm{NS} / \mathrm{C}-\mathrm{g}-\mathrm{C}_{3} \mathrm{~N}_{4} / \mathrm{TPTZ}-1000$ slightly decreases by $12 \mathrm{mV}$, demonstrating the superior durability of the $\mathrm{Fe} / \mathrm{NS} / \mathrm{C}-\mathrm{g}-\mathrm{C}_{3} \mathrm{~N}_{4} / \mathrm{TPTZ}-1000$ catalyst, due to the robust structure of Fe and $\mathrm{N}$ anchored in carbon matrix and the low yield of corrosive $\mathrm{H}_{2} \mathrm{O}_{2}$. In sharp contrast, the $E_{1 / 2}$ of $\mathrm{Pt} / \mathrm{C}$ remarkably decreases by $35 \mathrm{mV}$ after only 5000 cycles. The insufficient durability of the $\mathrm{Pt} / \mathrm{C}$ might suffer from the aggregation of Pt nanoparticles.

To further evaluate the potential for practical application, the Fe/NS/C-g- $\mathrm{C}_{3} \mathrm{~N}_{4} / \mathrm{TPTZ}-1000$ was assembled into a homemade primary $\mathrm{Zn}$-air battery as cathode catalyst. Figure 8a presents the polarization curves of Zn-air batteries with Fe/NS/C-g- $\mathrm{C}_{3} \mathrm{~N}_{4} / \mathrm{TPTZ}-1000$ and Pt/C as cathodes, respectively. The Zn-air battery with Fe/NS/C-g- $\mathrm{C}_{3} \mathrm{~N}_{4} / \mathrm{TPTZ}-1000$ catalyst exhibits an open-circuit voltage (OCV) of $1.385 \mathrm{~V}$ and a maximal power density of $225 \mathrm{~mW} \mathrm{~cm}^{-2}$ at a temperature of ca. $25^{\circ} \mathrm{C}$, which is quite comparable to that of $\mathrm{Pt} / \mathrm{C}$ with the $\mathrm{OCV}$ of $1.411 \mathrm{~V}$ and the maximal power density of $246 \mathrm{~mW} \mathrm{~cm}{ }^{-2}$. This performance outperforms the most of Zn-Air batteries utilizing analogous Fe-N-C cathode reported so far [37-40]. In the meantime, the long-term stability of a Zn-air battery 
with $\mathrm{Fe} / \mathrm{NS} / \mathrm{C}-\mathrm{g}-\mathrm{C}_{3} \mathrm{~N}_{4} / \mathrm{TPTZ}-1000$ was also tested by recording the galvanostatic discharge curves. As presented in Figure $8 \mathrm{~b}$, the $\mathrm{Zn}$-Air battery with Fe/NS/C-g- $\mathrm{C}_{3} \mathrm{~N}_{4} / \mathrm{TPTZ}-1000$ catalyst only presents a voltage loss of $4.03 \%$ after $20,000 \mathrm{~s}$ at a current density of $20 \mathrm{~mA} \mathrm{~cm}^{-2}$. For the $\mathrm{Pt} / \mathrm{C}$, the output voltage loss reaches $8.17 \%$ under the same conditions, demonstrating the improved durability of the $\mathrm{Fe} / \mathrm{NS} / \mathrm{C}-\mathrm{g}-\mathrm{C}_{3} \mathrm{~N}_{4} / \mathrm{TPTZ}-1000$. The slight fluctuation may due to the disturbance of testing circumstance such as humidity, which cannot be completely avoided. These results suggest that the as-prepared $\mathrm{Fe} / \mathrm{NS} / \mathrm{C}-\mathrm{g}-\mathrm{C}_{3} \mathrm{~N}_{4} / \mathrm{TPTZ}-1000$ catalyst has great potential to replace the precious metal catalysts in practical application of $\mathrm{Zn}$-air battery.

(a)

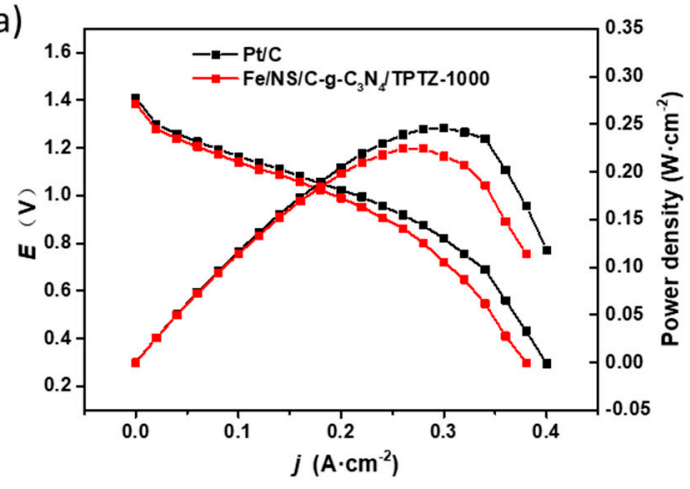

(b)

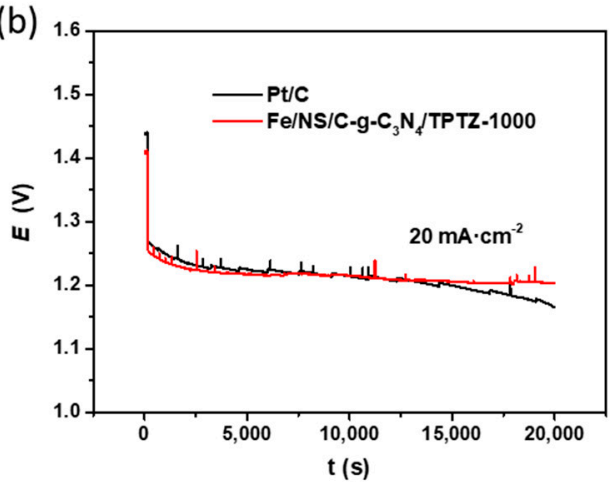

Figure 8. (a) Polarization curves and (b) discharge curves of Zn-air batteries with $\mathrm{Fe} / \mathrm{NS} / \mathrm{C}-$ g- $\mathrm{C}_{3} \mathrm{~N}_{4} / \mathrm{TPTZ}-1000$, and $20 \mathrm{wt} \% \mathrm{Pt} / \mathrm{C}$ as cathode catalysts at $298 \mathrm{~K}$.

\section{Experimental Section}

\subsection{Preparation of $g-C_{3} N_{4}$ Nanosheets}

Bulk g- $\mathrm{C}_{3} \mathrm{~N}_{4}$ powder was synthesized according to a procedure described in a previous paper [41]. Typically, dicyandiamide (Aldrich, Milwaukee, WI, USA, 99\%) powder was placed in an alumina crucible with cover and heated at $550{ }^{\circ} \mathrm{C}$ for $4 \mathrm{~h}$ in air with a ramp rate of $2.3^{\circ} \mathrm{C} / \mathrm{min}$. The obtained yellow agglomerates were grinded into powders. The light yellow $\mathrm{g}-\mathrm{C}_{3} \mathrm{~N}_{4}$ nanosheets were prepared by thermal etching of bulk g- $\mathrm{C}_{3} \mathrm{~N}_{4}$ in air at $500{ }^{\circ} \mathrm{C}$ for $2 \mathrm{~h}$ with a ramp rate of $5{ }^{\circ} \mathrm{C} / \mathrm{min}$.

\subsection{Catalyst Synthesis}

Commercial Ketjenblack EC 600J (KJ 600) carbon black was first pretreated in $6.0 \mathrm{M} \mathrm{HCl}$ solution for $12 \mathrm{~h}$ to remove metal impurities and collected by filtration. The obtained carbon black was then treated in concentrated $\mathrm{HNO}_{3}$ solution at $80^{\circ} \mathrm{C}$ for $8 \mathrm{~h}$ to introduce carboxyl groups [42].

In a typical synthesis, $125 \mathrm{mg}$ of 2,4,6-tri(2-pyridyl)-1,3,5-triazine (TPTZ, Adamas, Shanghai, China, $97 \%$ ), $125 \mathrm{mg}$ of $\mathrm{g}-\mathrm{C}_{3} \mathrm{~N}_{4}$ nanosheets, and $50 \mathrm{mg}$ of acid-treated $\mathrm{KJ} 600$ were dispersed in $50 \mathrm{~mL}$ of alcohol under vigorous stirring for $30 \mathrm{~min}$, then $\mathrm{Fe}(\mathrm{SCN})_{3}$ solution, prepared by mixing $\mathrm{FeCl}_{3}(0.2 \mathrm{M}$, $1.2 \mathrm{~mL}$ ) and potassium thiocyanate $(\mathrm{KSCN}, 0.2 \mathrm{M}, 3.6 \mathrm{~mL})$ in $50 \mathrm{~mL}$ of alcohol, was added into the suspension and stirred for another $30 \mathrm{~min}$. The solvent was then removed by rotary evaporation and vacuum drying at $80^{\circ} \mathrm{C}$ for $3 \mathrm{~h}$. The resulting powder was pyrolyzed at $800^{\circ} \mathrm{C}$ in a $\mathrm{N}_{2}$ atmosphere for $1 \mathrm{~h}$ with a ramp rate of $10^{\circ} \mathrm{C} / \mathrm{min}$. The pyrolyzed sample was subjected to acid leaching in $0.5 \mathrm{M} \mathrm{H}_{2} \mathrm{SO}_{4}$ solution at $80{ }^{\circ} \mathrm{C}$ for $8 \mathrm{~h}$ to remove unstable and inactive species followed by filtration and thoroughly washed with ultrapure water. The sample was finally vacuum dried to obtain the $\mathrm{Fe} / \mathrm{NS} / \mathrm{C}-\mathrm{g}-\mathrm{C}_{3} \mathrm{~N}_{4} / \mathrm{TPTZ}$ catalyst. As a comparison, $\mathrm{Fe} / \mathrm{NS} / \mathrm{C}-\mathrm{g}-\mathrm{C}_{3} \mathrm{~N}_{4}$ and $\mathrm{Fe} / \mathrm{NS} / \mathrm{C}-\mathrm{TPTZ}$ catalysts were prepared by the same procedure except using $250 \mathrm{mg}$ of $\mathrm{g}-\mathrm{C}_{3} \mathrm{~N}_{4}$ or $250 \mathrm{mg}$ of TPTZ as the single nitrogen precursor, respectively.

Moreover, the $\mathrm{Fe} / \mathrm{NS} / \mathrm{C}-\mathrm{g}-\mathrm{C}_{3} \mathrm{~N}_{4} / \mathrm{TPTZ}$ sample was heat-treated again at $800{ }^{\circ} \mathrm{C}, 900{ }^{\circ} \mathrm{C}$, and $1000{ }^{\circ} \mathrm{C}$ in a $\mathrm{N}_{2}$ atmosphere for $3 \mathrm{~h}$ to obtain the Fe/NS/C-g- $\mathrm{C}_{3} \mathrm{~N}_{4} / \mathrm{TPTZ}-\mathrm{T}(\mathrm{T}=800,900,1000)$ 
catalysts. The synthesis approaches for Fe/N/C-g- $\mathrm{C}_{3} \mathrm{~N}_{4} / \mathrm{TPTZ}-1000$ and NS/C-g- $\mathrm{C}_{3} \mathrm{~N}_{4} / \mathrm{TPTZ}-1000$ are the same as that for Fe/NS/C-g- $\mathrm{C}_{3} \mathrm{~N}_{4} / \mathrm{TPTZ}-1000$ without adding $\mathrm{KSCN}$ and $\mathrm{FeCl}_{3}$, respectively.

\subsection{Characterizations}

The morphology and elemental mapping of the samples were analyzed using field-emission transmission electron microscopy (FE-TEM, JEM-2100F, JEOL Ltd., Tokyo, Japan) with a working voltage of $200 \mathrm{kV}$. XRD analysis was performed using a D8 advance powder X-ray diffractometer (Bruker, Karlsruhe, Germany) with a $\mathrm{Cu} \mathrm{Ka}\left(\lambda=1.5418 \AA\right.$ ) at $0.2^{\circ} \mathrm{s}^{-1}$. The elemental composition and chemical states were measured by XPS (K-Alpha, Thermo Scientific, Waltham, MA, USA) with an $\mathrm{Al} \mathrm{Ka} X$-ray source. The surface areas and pore structures were characterized using a Micromeritics ASAP 2020 instrument (Micromeritics Instrument Corp., Norcross, GA, USA).

\subsection{Electrochemical Measurement}

All electrochemical measurements were conducted on a bipotentiostat (CHI-730E, Shanghai Chenhua, Shanghai, China) equipped with a rotating disk electrode (RDE) or rotating ring-disk electrode (RRDE) system (PINE Inc., Durham, NC, USA) at room temperature. An Ag/ AgCl electrode and a graphite plate were used as the reference and counter electrode, respectively. The potential has been experimentally corrected to the range of RHE by the following equation: $E(\mathrm{RHE})=E(\mathrm{Ag} / \mathrm{AgCl})+$ $0.956 \mathrm{~V}$. The electrolyte was $\mathrm{O}_{2}$-saturated $0.1 \mathrm{M} \mathrm{KOH}$ solution.

For all Fe-NS/PC catalysts, $12 \mathrm{mg}$ of catalyst was dispersed in the mixture of $0.5 \mathrm{~mL}$ of de-ionized water, $0.45 \mathrm{~mL}$ of isopropanol and $0.05 \mathrm{~mL}$ of $5 \mathrm{wt} \%$ Nafion solution (Aldrich) by sonication for $1 \mathrm{~h}$ to produce the ink. A certain volume of the catalyst ink was pipetted onto the pre-polished glassy carbon disk $\left(0.196 \mathrm{~cm}^{2}\right.$ for RDE and $0.2475 \mathrm{~cm}^{2}$ for RRDE) resulting a loading of $0.4 \mathrm{mg} \mathrm{cm}^{-2}$. For commercial $\mathrm{Pt} / \mathrm{C}$ catalyst (20 wt \%, ElectroChem, Inc., Woburn, MA, USA), the ink was prepared by dispersing $10 \mathrm{mg}$ catalyst in $1.0 \mathrm{~mL}$ of de-ionized water, $0.95 \mathrm{~mL}$ of isopropanol, and $0.05 \mathrm{~mL}$ of $5 \mathrm{wt} \%$ Nafion solution. The loading of the $\mathrm{Pt} / \mathrm{C}$ catalyst was $0.1 \mathrm{mg} \mathrm{cm}^{-2}$.

In RDE tests, ORR polarization curves were measured at a scan rate of $10 \mathrm{mV} \mathrm{s}^{-1}$. The electrode rotational speed was $1600 \mathrm{rpm}$. The background current was determined by recording the voltammogram in $\mathrm{N}_{2}$-saturated electrolyte. The accelerated durability tests (ADT) were carried out by cycling the potential in the range from 0.6 to $1.1 \mathrm{~V}$ in $\mathrm{O}_{2}$-saturated electrolyte with a scan rate of $50 \mathrm{mV} \mathrm{s}^{-1}$.

Hydrogen peroxide yield and the electron transfer number (n) can be calculated by the following equations with the potential of ring electrode fixed at $1.4 \mathrm{~V}$ (RHE) in RRDE:

$$
\begin{gathered}
\mathrm{H}_{2} \mathrm{O}_{2} \%=200 \% \times \frac{\frac{I_{r}}{\mathrm{~N}}}{\left|I_{d}\right|+\frac{I_{r}}{\mathrm{~N}}} \\
\mathrm{n}=4 \times \frac{\left|I_{d}\right|}{\left|I_{d}\right|+\frac{I_{r}}{\mathrm{~N}}}
\end{gathered}
$$

where $I_{d}$ is the disk current, $I_{r}$ is the ring current, $\mathrm{N}=0.37$ is the collection efficiency of the Pt ring.

\subsection{Primary Zn-Air Battery Test}

The cathode of the Zn-air battery was prepared by loading the Fe/NS/C-g- $\mathrm{C}_{3} \mathrm{~N}_{4} / \mathrm{TPTZ}-1000$ or $20 \mathrm{wt} \% \mathrm{Pt} / \mathrm{C}$ catalyst onto carbon fiber paper $(3.0 \times 4.0 \mathrm{~cm})$ with a catalyst loading of $1.0 \mathrm{mg} \mathrm{cm}^{-2}$. Electrolytic zinc powder was used as the anode. The electrolyte was $6.0 \mathrm{M} \mathrm{KOH}$ solution. Polarization curves and galvanostatic discharge curves were measured on Arbin battery testing system.

\section{Conclusions}

In summary, a Fe, N, S co-doped porous carbon as ORR electrocatalyst was developed based on the interaction of binary nitrogen precursors during the pyrolysis process. After secondary heat 
treatment, the $\mathrm{Fe} / \mathrm{NS} / \mathrm{C}-\mathrm{g}-\mathrm{C}_{3} \mathrm{~N}_{4} / \mathrm{TPTZ}-1000$ catalyst displays superior ORR activity and durability in alkaline media, in comparison with the commercial $\mathrm{Pt} / \mathrm{C}$. Enhanced ORR activity and durability can be attributed to its good porous structure, high surface area, high contents of pyridinic $\mathrm{N}$ and graphitic $\mathrm{N}$, and the synergy of $\mathrm{N}$ and $\mathrm{S}$ co-doping. Moreover, the Zn-air battery assembled with $\mathrm{Fe} / \mathrm{NS} / \mathrm{C}-\mathrm{g}-\mathrm{C}_{3} \mathrm{~N}_{4} / \mathrm{TPTZ}-1000$ as a cathode exhibits comparable power density and better stability than that of the $\mathrm{Pt} / \mathrm{C}$, demonstrating its potential for substituting precious metal catalysts in practical energy devices.

Supplementary Materials: The following are available online at http://www.mdpi.com/2073-4344/8/4/ 158/s1, Figure S1: Thermogravimetric analysis (TGA) of (a) $\mathrm{g}-\mathrm{C}_{3} \mathrm{~N}_{4}$ and (b)TPTZ under $\mathrm{N}_{2}$ atmosphere, Figure S2: ORR polarization curves of $\mathrm{Fe} / \mathrm{N} / \mathrm{C}-\mathrm{g}-\mathrm{C}_{3} \mathrm{~N}_{4} / \mathrm{TPTZ}-1000$, NS/C-g- $\mathrm{C}_{3} \mathrm{~N}_{4} / \mathrm{TPTZ}-1000$ and $\mathrm{Fe} / \mathrm{NS} / \mathrm{C}$-g- $\mathrm{C}_{3} \mathrm{~N}_{4} / \mathrm{TPTZ}-1000$ in $\mathrm{O}_{2}$-saturated $0.1 \mathrm{M} \mathrm{KOH}$ solution with a rotational speed of $1600 \mathrm{rpm}$ and a scan rate of $10 \mathrm{mV} / \mathrm{s}$, Figure S3: The polarization curves of Fe/NS/C-g- $\mathrm{C}_{3} \mathrm{~N}_{4} / \mathrm{TPTZ}-1000$ catalyst before and after adding $\mathrm{SCN}^{-}$and after rinsing and replacing fresh $\mathrm{O}_{2}$-saturated $0.1 \mathrm{M} \mathrm{KOH}$ solution, Table S1: The element contents of $\mathrm{Fe} / \mathrm{NS} / \mathrm{C}-\mathrm{g}-\mathrm{C}_{3} \mathrm{~N}_{4}, \mathrm{Fe} / \mathrm{NS} / \mathrm{C}-\mathrm{TPTZ}$ and $\mathrm{Fe} / \mathrm{NS} / \mathrm{C}-\mathrm{g}-\mathrm{C}_{3} \mathrm{~N}_{4} / \mathrm{TPTZ}$ obtained by XPS, Table S2: The element contents of Fe/NS/C-g- $\mathrm{C}_{3} \mathrm{~N}_{4} / \mathrm{TPTZ}-\mathrm{T}(\mathrm{T}=800,900,1000)$ obtained by XPS, Table S3: Comparison of ORR activity of $\mathrm{Fe} / \mathrm{NS} / \mathrm{C}-\mathrm{g}-\mathrm{C}_{3} \mathrm{~N}_{4} / \mathrm{TPTZ}, \mathrm{Fe} / \mathrm{NS} / \mathrm{C}-\mathrm{g}-\mathrm{C}_{3} \mathrm{~N}_{4} / \mathrm{TPTZ}-\mathrm{T}(\mathrm{T}=800,900,1000)$ and Pt/C catalysts.

Acknowledgments: The financial supports from the National Key Research and Development Program of China (grant no. 2017YFA0206500) and the National Natural Science Foundation of China (grant no. 21673275, 21533005) are greatly appreciated.

Author Contributions: Xiao Liu, Chi Chen, Zhiqing Zou, and Hui Yang conceived and designed the experiments; Xiao Liu performed the experiments; Xiao Liu, Chi Chen, Qingqing Cheng, and Liangliang Zou analyzed the data; Xiao Liu and Chi Chen wrote the paper; Zhiqing Zou and Hui Yang managed all the experiments and the writing process as the corresponding authors.

Conflicts of Interest: The authors declare no conflict of interest.

\section{References}

1. Cui, X.; Yang, S.; Yan, X.; Leng, J.; Shuang, S.; Ajayan, P.M.; Zhang, Z. Pyridinic-Nitrogen-Dominated Graphene Aerogels with Fe-N-C Coordination for Highly Efficient Oxygen Reduction Reaction. Adv. Funct. Mater. 2016, 26, 5708-5717. [CrossRef]

2. Zhu, Z.; Yang, Y.; Guan, Y.; Xue, J.; Cui, L. Constructing of cobalt-embedded in nitrogen-doped carbon material with desired porosity derived from MOFs confined growth within graphene aerogel as a superior catalyst towards HER and ORR. J. Mater. Chem. A 2016, 4, 15536-15545. [CrossRef]

3. Yang, J.; Liu, D.J.; Kariuki, N.N.; Chen, L.X. Aligned carbon nanotubes with built-in $\mathrm{FeN}_{4}$ active sites for electrocatalytic reduction of oxygen. Chem. Commun. 2008, 36, 329-331. [CrossRef]

4. Zeng, L.; Cui, X.; Chen, L.; Ye, T.; Huang, W.; Ma, R.; Zhang, X.; Shi, J. Non-noble bimetallic alloy encased in nitrogen-doped nanotubes as a highly active and durable electrocatalyst for oxygen reduction reaction. Carbon 2017, 114, 347-355. [CrossRef]

5. Liu, H.; Shi, Z.; Zhang, J.; Zhang, L.; Zhang, J. Ultrasonic spray pyrolyzed iron-polypyrrole mesoporous spheres for fuel cell oxygen reduction electrocatalysts. J. Mater. Chem. 2009, 19, 468-470. [CrossRef]

6. Liang, H.W.; Wei, W.; Wu, Z.S.; Feng, X.; Müllen, K. Mesoporous Metal-Nitrogen-Doped Carbon Electrocatalysts for Highly Efficient Oxygen Reduction Reaction. J. Am. Chem. Soc. 2013, 135, 16002-16005. [CrossRef] [PubMed]

7. Wu, G.; Zelenay, P. Nanostructured nonprecious metal catalysts for oxygen reduction reaction. Acc. Chem. Res. 2013, 46, 1878-1889. [CrossRef] [PubMed]

8. Zhang, J.; Dai, L. Heteroatom-doped graphitic carbon catalysts for efficient electrocatalysts of oxygen reduction reaction. ACS Catal. 2015, 5, 7244-7253. [CrossRef]

9. Jia, Q.; Ramaswamy, N.; Hafiz, H.; Tylus, U.; Strickland, K.; Wu, G.; Barbiellini, B.; Bansil, A.; Holby, E.F.; Zelenay, P. Experimental observation of redox-induced Fe-N switching behavior as a determinant role for oxygen reduction activity. ACS Nano 2015, 9, 12496-12505. [CrossRef] [PubMed]

10. Kone, I.; Xie, A.; Tang, Y.; Chen, Y.; Liu, J.; Chen, Y.; Sun, Y.; Yang, X.; Wan, P. Hierarchical Porous Carbon Doped with Iron-Nitrogen-Sulfur for Efficient Oxygen Reduction Reaction. ACS Appl. Mater. Interfaces 2017, 9, 20963-20973. [CrossRef] [PubMed] 
11. Yu, H.; Fisher, A.; Cheng, D.; Cao, D. Cu, N-codoped Hierarchical Porous Carbons as Electrocatalysts for Oxygen Reduction Reaction. ACS Appl. Mater. Interfaces 2016, 8, 21431-21439. [CrossRef] [PubMed]

12. Qiao, M.; Tang, C.; He, G.; Qiu, K.; Binions, R.; Parkin, I.; Zhang, Q.; Guo, Z.; Titirici, M. Graphene/ nitrogen-doped porous carbon sandwiches for the metal-free oxygen reduction reaction: Conductivity versus active sites. J. Mater. Chem. A 2016, 4, 12658-12666. [CrossRef]

13. Lefèvre, M.; Proietti, E.; Jaouen, F.; Dodelet, J.P. Iron-based catalysts with improved oxygen reduction activity in polymer electrolyte fuel cells. Science 2009, 324, 71-74. [CrossRef] [PubMed]

14. Li, Z.; Sun, H.; Wei, L.; Jiang, W.J.; Wu, M.; Hu, J.S. Lamellar Metal Organic Framework-Derived Fe-N-C Non-Noble Electrocatalysts with Bimodal Porosity for Efficient Oxygen Reduction. ACS Appl. Mater. Interfaces 2017, 9, 5272-5278. [CrossRef] [PubMed]

15. Gupta, S.; Zhao, S.; Ogoke, O.; Lin, Y.; Xu, H.; Wu, G. Engineering Favorable Morphology and Structure of Fe-N-C Oxygen-Reduction Catalysts through Tuning of Nitrogen/Carbon Precursors. ChemSusChem 2017, 10, 774-785. [CrossRef] [PubMed]

16. Fu, X.; Zamani, P.; Choi, J.Y.; Hassan, F.M.; Jiang, G.; Higgins, D.C.; Zhang, Y.; Hoque, M.A.; Chen, Z. In Situ Polymer Graphenization Ingrained with Nanoporosity in a Nitrogenous Electrocatalyst Boosting the Performance of Polymer-Electrolyte-Membrane Fuel Cells. Adv. Mater. 2016, 29, 1604456. [CrossRef] [PubMed]

17. Chung, H.T.; Cullen, D.A.; Higgins, D.; Sneed, B.T.; Holby, E.F.; More, K.L.; Zelenay, P. Direct atomic-level insight into the active sites of a high-performance PGM-free ORR catalyst. Science 2017, 357, 479-484. [CrossRef] [PubMed]

18. Wang, Y.C.; Lai, Y.J.; Song, L.; Zhou, Z.Y.; Liu, J.G.; Wang, Q.; Yang, X.D.; Chen, C.; Shi, W.; Zheng, Y.P.; et al. S-Doping of an Fe/N/C ORR Catalyst for Polymer Electrolyte Membrane Fuel Cells with High Power Density. Angew. Chem. Int. Ed. 2015, 127, 10045-10048. [CrossRef]

19. Chen, P.; Zhou, T.; Xing, L.; Xu, K.; Tong, Y.; Xie, H.; Zhang, L.; Yan, W.; Chu, W.; Wu, C. Atomically Dispersed Iron-Nitrogen Species as Electrocatalysts for Bifunctional Oxygen Evolution and Reduction Reactions. Angew. Chem. Int. Ed. 2017, 56, 610-614. [CrossRef] [PubMed]

20. Tian, J.; Morozan, A.; Sougrati, M.T.; Chenitz, R.; Dodelet, J.P.; Jones, D.; Jaouen, F. Optimized synthesis of Fe/N/C cathode catalysts for PEM fuel cells: A matter of iron-ligand coordination strength. Angew. Chem. Int. Ed. 2013, 52, 6867-6870. [CrossRef] [PubMed]

21. Yang, L.; Kong, J.; Zhou, D.; Ang, J.M.; Phua, S.L.; Yee, W.A.; Liu, H.; Huang, Y.; Lu, X. Transition-Metal-Ion-Mediated Polymerization of Dopamine: Mussel-Inspired Approach for the Facile Synthesis of Robust Transition-Metal Nanoparticle-Graphene Hybrids. Chem. Eur. J. 2014, 20, 7776-7783. [CrossRef] [PubMed]

22. Zhou, D.; Yang, L.; Yu, L.; Kong, J.; Yao, X.; Liu, W.; Xu, Z.; Lu, X. Fe/N/C hollow nanospheres by $\mathrm{Fe}(\mathrm{III})$-dopamine complexation-assisted one-pot doping as nonprecious-metal electrocatalysts for oxygen reduction. Nanoscale 2015, 7, 1501-1509. [CrossRef] [PubMed]

23. Jaouen, F.; Herranz, J.; Lefèvre, M.; Dodelet, J.P.; Kramm, U.I.; Herrmann, I.; Bogdanoff, P.; Maruyama, J.; Nagaoka, T.; Garsuch, A. Cross-laboratory experimental study of non-noble-metal electrocatalysts for the oxygen reduction reaction. ACS Appl. Mater. Interfaces 2009, 1, 1623-1639. [CrossRef] [PubMed]

24. Jaouen, F.; Lefèvre, M.; Dodelet, J.P.; Cai, M. Heat-Treated Fe/N/C Catalysts for $\mathrm{O}_{2}$ Electroreduction: Are Active Sites Hosted in Micropores? J. Phys. Chem. B 2006, 110, 5553-5558. [CrossRef] [PubMed]

25. Yasuda, S.; Furuya, A.; Uchibori, Y.; Kim, J.; Murakoshi, K. Iron-Nitrogen-Doped Vertically Aligned Carbon Nanotube Electrocatalyst for the Oxygen Reduction Reaction. Adv. Funct. Mater. 2016, 26, 738-744. [CrossRef]

26. Choi, I.A.; Kwak, D.H.; Han, S.B.; Park, J.Y.; Park, H.S.; Ma, K.B.; Kim, D.H.; Won, J.E.; Park, K.W. Doped porous carbon nanostructures as non-precious metal catalysts prepared by amino acid glycine for oxygen reduction reaction. Appl. Catal. B Environ. 2017, 211, 235-244. [CrossRef]

27. Liang, W.; Chen, J.; Liu, Y.; Chen, S. Density-functional-theory calculation analysis of active sites for four-electron reduction of $\mathrm{O}_{2}$ on Fe/N-doped graphene. ACS Catal. 2014, 4, 4170-4177. [CrossRef]

28. Xiao, H.; Shao, Z.G.; Zhang, G.; Gao, Y.; Lu, W.; Yi, B. Fe-N-carbon black for the oxygen reduction reaction in sulfuric acid. Carbon 2013, 57, 443-451. [CrossRef]

29. Saidi, W.A. Oxygen reduction electrocatalysis using N-doped graphene quantum-dots. J. Phys. Chem. Lett. 2013, 4, 4160-4165. [CrossRef] 
30. Liang, J.; Jiao, Y.; Jaroniec, M.; Qiao, S.Z. Sulfur and nitrogen dual-doped mesoporous graphene electrocatalyst for oxygen reduction with synergistically enhanced performance. Angew. Chem. Int. Ed. 2012, 51, 11496-11500. [CrossRef] [PubMed]

31. Jiang, T.; Wang, Y.; Wang, K.; Liang, Y.; Wu, D.; Tsiakaras, P.; Song, S. A novel sulfur-nitrogen dual doped ordered mesoporous carbon electrocatalyst for efficient oxygen reduction reaction. Appl. Catal. B Environ. 2016, 189, 1-11. [CrossRef]

32. Ai, W.; Luo, Z.; Jiang, J.; Zhu, J.; Du, Z.; Fan, Z.; Xie, L.; Zhang, H.; Huang, W.; Yu, T. Nitrogen and sulfur codoped graphene: Multifunctional electrode materials for high-performance Li-ion batteries and oxygen reduction reaction. Adv. Mater. 2014, 26, 6186-6192. [CrossRef] [PubMed]

33. Chen, C.; Yang, X.D.; Zhou, Z.Y.; Lai, Y.J.; Rauf, M.; Wang, Y.; Pan, J.; Zhuang, L.; Wang, Q.; Wang, Y.C. Aminothiazole-derived N, S, Fe-doped graphene nanosheets as high performance electrocatalysts for oxygen reduction. Chem. Commun. 2015, 51, 17092-17095. [CrossRef] [PubMed]

34. Shen, H.; Gracia-Espino, E.; Ma, J.; Zang, K.; Luo, J.; Wang, L.; Gao, S.; Mamat, X.; Hu, G.; Wagberg, T. Synergistic Effects between Atomically Dispersed Fe-N-C and C-S-C for the Oxygen Reduction Reaction in Acidic Media. Angew. Chem. Int. Ed. 2017, 56, 13800-13804. [CrossRef] [PubMed]

35. Zeng, S.; Lyu, F.; Nie, H.; Zhan, Y.; Bian, H.; Tian, Y.; Li, Z.; Wang, A.; Lu, J.; Li, Y.Y. Facile fabrication of $\mathrm{N} / \mathrm{S}$-doped carbon nanotubes with $\mathrm{Fe}_{3} \mathrm{O}_{4}$ nanocrystals enchased for lasting synergy as efficient oxygen reduction catalysts. J. Mater. Chem. A 2017, 5, 13189-13195. [CrossRef]

36. Ren, G.; Lu, X.; Li, Y.; Zhu, Y.; Dai, L.; Jiang, L. Porous Core-Shell $\mathrm{Fe}_{3} \mathrm{C} \mathrm{Embedded} \mathrm{N-doped} \mathrm{Carbon}$ Nanofibers as an Effective Electrocatalysts for Oxygen Reduction Reaction. ACS Appl. Mater. Interfaces 2016, 8, 4118-4125. [CrossRef] [PubMed]

37. Cao, L.; Li, Z.; Gu, Y.; Li, D.; Su, K.; Yang, D.; Cheng, B. Rational design of N-doped carbon nanobox-supported $\mathrm{Fe} / \mathrm{Fe}_{2} \mathrm{~N} / \mathrm{Fe}_{3} \mathrm{C}$ nanoparticles as efficient oxygen reduction catalysts for $\mathrm{Zn}$-air batteries. J. Mater. Chem. A 2017, 5, 11340-11347. [CrossRef]

38. Zhao, Y.; Lai, Q.; Wang, Y.; Zhu, J.; Liang, Y.Y. Interconnected Hierarchically Porous Fe, N-Codoped Carbon Nanofibers as Efficient Oxygen Reduction Catalysts for Zn-Air Batteries. ACS Appl. Mater. Interfaces 2017, 9 , 16178-16186. [CrossRef] [PubMed]

39. Yang, J.; Toshimitsu, F.; Yang, Z.; Fujigaya, T.; Nakashima, N. Pristine carbon nanotube/iron phthalocyanine hybrids with a well-defined nanostructure show excellent efficiency and durability for oxygen reduction reaction. J. Mater. Chem. A 2016, 5, 1184-1191. [CrossRef]

40. Cai, P.; Hong, Y.; Ci, S.; Wen, Z. In situ integration of CoFe alloy nanoparticles with nitrogen-doped carbon nanotubes as advanced bifunctional cathode catalysts for Zn-air batteries. Nanoscale 2016, 8, 20048-20055. [CrossRef] [PubMed]

41. Niu, P.; Zhang, L.; Liu, G.; Cheng, H.M. Graphene-like carbon nitride nanosheets for improved photocatalytic activities. Adv. Funct. Mater. 2012, 22, 4763-4770. [CrossRef]

42. Choi, J.Y.; Hsu, R.S.; Chen, Z. Highly active porous carbon-supported nonprecious metal-N electrocatalyst for oxygen reduction reaction in PEM fuel cells. J. Phys. Chem. C 2010, 114, 8048-8053. [CrossRef]

(C) 2018 by the authors. Licensee MDPI, Basel, Switzerland. This article is an open access article distributed under the terms and conditions of the Creative Commons Attribution (CC BY) license (http:/ / creativecommons.org/licenses/by/4.0/). 